\title{
WWF's Quarter-century of Conservation
}

In the 25 years since WWF* was founded, it has become the largest private international Nature conservation organization. It now has more than a million regular supporters and 23 national affiliates, as well as many associates practically throughout the world. WWF has channelled more than US \$110 millions into projects in 130 countries.

When WWF's conservation efforts began, the constituency for conservation was preoccupied mainly with disappearing flora and fauna, and no government had a full ministry of the environment. Today, few issues concern people more than the state of their environment. There are more than 100 environmental ministries and departments world-wide, and conservation is a plank in practically every political party platform.

Parliaments are requiring international banks and aid agencies to carry out environmental impact assessments before approving development loans and grants. Corporations increasingly appoint boardlevel executives responsible for conservation policy. School curricula give more and more attention to natural resource protection. Nature programmes lead television ratings, and newspapers routinely employ environmental reporters, as conservation issues are now front-page news.

Back in 1961, rescue missions were needed to protect the world's plants and animals from the growing threats posed by post-war acceleration in development world-wide. WWF concentrated on saving species, such as the nearly-extinct Arabian Oryx, and protected areas such as Spain's Coto Doñana which was threatened with conversion into farmland. But as the importance of ecological links become more apparent, conservation is increasingly seen in terms of human development.

Operation Tiger was one example of this changing approach. Tigers faced extinction, and could only be saved by protecting their prey and, in turn, the prey's habitat. By safeguarding 'the tiger', forests - vital to Man as they protect soil and water-were also saved.

Over the years, WWF has worked with IUCN* also in other ways to protect the environment. It has influenced the agenda of national and international conservation, and helped to spotlight crucial issues by launching high-visibility international campaigns. WWF launched the first international publicity campaign to save tropical forests and, together with IUCN, the first international campaigns to protect plants and wetlands.

Now, population growth and technological advances require a broader approach. This is reflected in WWF's newest campaign - conservation awareness, training, and education - which will be launched at Assisi this September.

From the outset, WWF worked with others who shared its aims. It has, for the past 25 years, provided substantial support to IUCN, the International Council for Bird Protection, the International Waterfowl Research Bureau, and the Charles Darwin Foundation.

It has worked closely with governments on every normally-inhabited continent and has helped to strengthen non-governmental conservation groups in developing countries. It has helped to establish youth clubs and provided them with educational materials, and it has supported the training of protectedarea managers, wildlife rangers, ecologists, and teachers. It has also encouraged excellence and relevance in environmental films, television programming, and publishing, and has collaborated with trade and industry associations to improve environmental practices, while significantly reinforcing the work of those monitoring the wildlife trade.

WWF will continue to strengthen old partnerships as well as seek new ones. At Assisi this year, WWF will launch a new initiative by establishing a conservation dialogue with five of the world's major religions. Together with the European Council of International Schools, WWF is developing a course in the conservation of Nature for use in international schools world-wide. It is also opening up a new category of official WWF Associates in order to strengthen its links with non-governmental organizations in those developing countries in which its activities are being focused.

The effective spending of money on conservation activities requires as much skill as does raising it. In programming expenditure, WWF continues to be guided by the principles and objectives of the World Conservation Strategy, which was 'Prepared by IUCN with the advice, cooperation and financial assistance of UNEP and WWF' and published in 1980. WWF International and its national organizations ensure the scientific validity of their conservation programmes and projects by close collaboration with many conservation organizations, particularly IUCN, and through the scientific expertise represented within their Boards, Advisory Committees, and staff.

All of WWF International's fund-raising and administrative costs continue to be covered by 'earned income' from endowment, trading, and royalties. This allows WWF to make sure that all donated funds received at Headquarters are used for conservation purposes, and nothing else.

\author{
Charles de HaEs, Director-General \\ WWF International \\ World Conservation Centre \\ Avenue du Mont-Blanc \\ 1196 Gland, Switzerland.
}

*WWF and IUCN being two of the three nominal co-founders of our Journal's owning and copyright-holding Foundation, we have, since the commencement of Environmental Conservation in 1974, upheld their emblems and titles on its front cover. It is contemplated that IUCN's plans will be 